\title{
EFFECT OF METSULFURON ON THE VIABILITY OF RAGWORT AND NODDING THISTLE SEEDS
}

\author{
T.K. JAMES ${ }^{1}$, A. RAHMAN ${ }^{1}$ and M.J. CORNWELL ${ }^{2}$ \\ ${ }^{1}$ AgResearch, Ruakura Research Centre, Private Bag 3123, Hamilton \\ ${ }^{2}$ Du Pont (New Zealand) Ltd, Private Bag 97641, Manukau
}

\begin{abstract}
Metsulfuron-methyl (Escort, $0.6 \mathrm{~g}$ ai/10 litre) was applied to ragwort (Senecio jacobaea) and nodding thistle (Carduus nutans) plants at different stages of flower development. The glasshouse grown plants were sprayed when the buds were fully developed but not open, when the flowers were partially open, or when the flowers were fully open. The viability of seeds produced by these plants was evaluated by germination in our laboratory $\left(12-27 \times 20\right.$ seeds, $14 \mathrm{~h}$ photoperiod, $25^{\circ} \mathrm{C} / 15^{\circ} \mathrm{C}$ day/night temperature) and in the Seed Testing Laboratory $\left(10 \times 300\right.$ seeds, $0.2 \% \mathrm{KNO}_{3}, 12 \mathrm{~h}$ photoperiod, $30^{\circ} \mathrm{C} / 20^{\circ} \mathrm{C}$ day/night temperature) at Palmerston North. The flower buds treated at the early development stage mostly rotted before full development and seed production was about half of that from the other two development stages and from untreated control. Seed production from untreated flowers averaged 35 seeds/flower for ragwort and 276 seeds/flower for nodding thistle. More importantly, none of the ragwort or nodding thistle seeds collected from the flowers treated with metsulfuron-methyl germinated. Seed germination from the control plants was $16 \%$ for the ragwort and $48 \%$ for nodding thistle in our laboratory, whereas the Seed Testing Laboratory recorded $37 \%$ and $53 \%$ germination respectively.
\end{abstract}

\section{PLANT PEST INFORMATION NETWORK (PPIN): AN ACTIVE INFORMATION SYSTEM TO SUPPORT YOUR RESEARCH}

\author{
K.L. BEAL \\ National Plant Pest Reference Laboratory, Ministry of Agriculture and Forestry, \\ PO Box 24, Gerald Street, Lincoln, Mid Canterbury, New Zealand
}

Surveillance information is the cornerstone of both agricultural security and market access for New Zealand. Knowledge of our pest and disease status is used in development of quarantine specifications and to support negotiations with our trading partners. A key component of New Zealand's surveillance programme is reporting new plant pest records as facilitated by the Biosecurity Act 1993 (as amended in the Biosecurity Amendment Act 1997). New plant pest records required to be reported include: organisms new to New Zealand, new plant pest host associations, new plant pest distributions. The Plant Pest Information Network (PPIN) is a national database and scientific network for the collection, collation, management and dissemination of plant pest surveillance information. PPIN is maintained by the National Plant Pest Reference Laboratory (NPPRL). It holds records of pest/organism occurrence, their hosts and distribution including records on fungi, bacteria, viruses, nematodes, insects etc. Currently PPIN holds approximately 14,000 association records and 20,000 observation records for main export/import crops. Other crops, including those of interest to the forestry sector, will be included as information becomes available. Input from the scientific community will help build and maintain an accurate, up to date set of surveillance data for New Zealand. New or unpublished/published records should be forwarded to the PPIN Administrator for their inclusion into the database. 